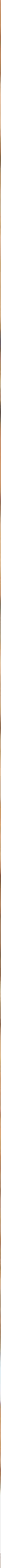

IN VITRO STUDIE NAAR DE INVLOED VAN INTRINSIEK EN MICROBIEEL FYTASE OP DE AFBRAAK VAN FYTINEZUUR IN BIOLOGISCHE GETEELDE GRONDSTOFFEN VOOR DE DIERHOUDERIJ

Een verkennende studie

L.H. de Jonge, P.G. van Wikselaar, P. Bikker en M.M. van Krimpen 



\section{IN VITRO STUDIE NAAR DE INVLOED VAN INTRINSIEK EN MICROBIEEL FYTASE OP DE AFBRAAK VAN FYTINEZUUR IN BIOLOGISCHE GETEELDE GRONDSTOFFEN VOOR DE DIERHOUDERIJ}

Een verkennende studie

L.H. de Jonge ${ }^{1}$, P.G. van Wikselaar ${ }^{2}$, P. Bikker ${ }^{2}$ en M.M. van Krimpen²

${ }^{1}$ Wageningen Universiteit \& Research, leerstoelgroep Diervoeding,

${ }^{2}$ Wageningen Livestock Research, afdeling Diervoeding

Dit onderzoek is uitgevoerd als onderdeel van de publiek-private samenwerking (PPS) "Vermindering fosforexcretie door biologisch gehouden varkens en pluimvee - TKI-AF-15105", en is medegefinancierd door het Ministerie van Economische Zaken, in het kader van het Beleidsondersteunend Onderzoek (projectnummer BO-22.04-007-006).

Wageningen Livestock Research

Wageningen, januari 2017

Rapport 1006 
L.H. de Jonge, P.G. van Wikselaar, P. Bikker en M.M. van Krimpen, 2016. In vitro studie naar de invloed van intrinsiek en microbieel fytase op de afbraak van fytinezuur in biologische geteelde grondstoffen voor de dierhouderij; Een verkennende studie. Wageningen Livestock Research, Rapport 1006.

In deze studie is de bruikbaarheid van intrinsiek fytase vanuit grondstoffen voor de afbraak van fytinezuur in grondstoffen onderzocht. De enzymatische omzetbaarheid van fytinezuur naar oplosbaar anorganische fosfaat werd in vitro bepaald met en zonder toevoeging microbieel fytase. De afbraak van fytinezuur is gemeten in combinaties van grondstoffen met een hoge intrinsieke fytase activiteit en grondstoffen met een hoog fytinezuurgehalte.

In this study, the usefulness of intrinsic phytase of plant ingredients for degrading phytate was investigated. The enzymatic conversion from phytate to soluble inorganic phosphate was determined in vitro with and without addition of microbial phytase. Phytate degradation was measured in mixtures in which ingredients with a high intrinsic phytase activity and ingredients with a high phytate content were combined.

Dit rapport is gratis te downloaden op http://dx.doi.org/10.18174/402527 of op www.wur.nl/livestock-research (onder Wageningen Livestock Research publicaties).

\section{(C) 2016 Wageningen Livestock Research}

Postbus 338, 6700 AH Wageningen, T 03174839 53, E info.livestockresearch@wur.nl, www.wur.nl/livestock-research. Wageningen Livestock Research is onderdeel van Wageningen University \& Research.

Wageningen Livestock Research aanvaardt geen aansprakelijkheid voor eventuele schade voortvloeiend uit het gebruik van de resultaten van dit onderzoek of de toepassing van de adviezen.

Alle rechten voorbehouden. Niets uit deze uitgave mag worden vermenigvuldigd en/of openbaar gemaakt worden door middel van druk, fotokopie, microfilm of op welke wijze dan ook zonder voorafgaande toestemming van de uitgever of auteur. onderzoeksopdrachten zijn de Algemene Voorwaarden van de Animal Sciences Group van toepassing. Deze zijn gedeponeerd bij de Arrondissementsrechtbank Zwolle. 


\section{Inhoud}

$\begin{array}{ll}\text { Woord vooraf } & 5\end{array}$

$\begin{array}{ll}\text { Samenvatting } & 7\end{array}$

1

$\begin{array}{lr}\text { Inleiding } & 9\end{array}$

2.

$\begin{array}{ll}\text { Materiaal en Methode } & 11\end{array}$

2.1 Materiaal 11

2.2 Methode 11

2.2.1 Karakterisering grondstoffen 11

2.2.2 Enzymatisch omzetbaarheid fytinezuur 11

2.2.3 Activiteit fytase in grondstoffen 12

2.2.4 Effectiviteit intrinsiek fytase $\quad 12$

2.2.5 Pepsine- $\mathrm{HCl}$ bestendigheid van intrinsiek fytase 13

$\begin{array}{llr}3 . & 14\end{array}$

$\begin{array}{lll}3.1 & \text { Karakterisering grondstoffen } & 14\end{array}$

3.2 Enzymatische omzetbaarheid fytinezuur 14

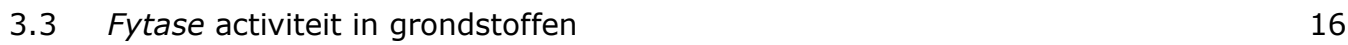

$\begin{array}{lll}3.4 & \text { Effectiviteit intrinsiek fytase } & 17\end{array}$

$\begin{array}{lll}3.5 & \text { Pepsine- } \mathrm{HCl} \text { bestendigheid intrinsiek fytase } & 17\end{array}$

$\begin{array}{llr}4 . & 19\end{array}$

$\begin{array}{lr}\text { 5. Conclusies } & 20\end{array}$

$\begin{array}{ll}\text { Referenties } & \mathbf{2 1}\end{array}$

Bijlage 1 Protocol Enzymatische omzetbaarheid fytinezuur P 22

Bijlage 2 Protocol: Bepaling van de fytase activiteit 23

Bijlage 3 Protocol: Bepaling van de effectiviteit van intrinsiek fytase $\quad 24$

Bijlage 4 Protocol: Pepsine-HCl bestendigheid van intrinsiek fytase 25 



\section{Woord vooraf}

In verband met het streven naar evenwichtsbemesting zijn de fosfaatgebruiksnormen de afgelopen jaren geleidelijk verlaagd. Op dit moment is fosfaat de limiterende factor voor de hoeveelheid mest die per hectare aangewend mag worden. Voor de biologische akkerbouwer zijn deze fosfaatgebruiksnormen een groot knelpunt, omdat wanneer de maximale hoeveelheid fosfaat is aangevoerd, er nog steeds ruimte en behoefte is om stikstof aan te voeren, terwijl deze niet als kunstmest mag worden aangevoerd. Voor de biologische varkens- en pluimveehouder is de mestafzet door beperkte plaatsingsruimte van biologische mest binnen Nederland problematisch vanwege o.a. een ongunstige (lage) N/P-verhouding in de mest. De excretie van fosfor $(P)$ via de mest van biologisch gehouden varkens en pluimvee is hoger ten opzichte van mest van gangbaar gehouden dieren. Het hogere P-gehalte hangt samen met het feit dat het enzym fytase niet toegevoegd mag worden aan biologisch voer. In deze studie is nagegaan hoe de werking van planteigen (intrinsiek) fytase in biologische voeders beter benut kan worden, o.a. door grondstoffenkeuze en het productieproces van het voer optimaal af te stemmen op de bescherming van het intrinsiek fytase. In dit project is samengewerkt met producenten van biologisch veevoer en vertegenwoordigers van de biologische varkens- en pluimveehouders. De auteurs bedanken de partners van het project voor hun waardevolle inbreng.

Marinus van Krimpen, projectleider 


\section{Samenvatting}

Het fosfor in plantaardige grondstoffen is voor een groot deel gebonden aan fytaat. Aangenomen wordt dat de meeste eenmagigen (varkens en pluimvee) het enzym fytase missen, wat nodig is om fosfor te splitsen van het fytaat. Hierdoor is het fytaat-gebonden fosfor in het algemeen voor eenmagigen slecht verteerbaar en opneembaar. In voeders voor de gangbare veehouderij wordt op grote schaal exogeen fytase toegevoegd, waardoor de verteerbaarheid van fosfor sterk toeneemt (van ca. 30 naar 70\%). Op deze manier kan het fosforgehalte van het voer omlaag gebracht worden, zonder dat de $v$ fosforvoorziening van de dieren en daarmee de gezondheid en dierprestaties in gevaar komt. Commercieel beschikbare producten met (exogeen) fytase worden geproduceerd door genetisch gemodificeerde micro-organismen, waardoor dit enzym niet toegepast mag worden in biologische voeders.

Fytase komt echter ook van nature voor in met name granen en dit intrinsieke fytase kan helpen bij het verhogen van de fosfor verteerbaarheid/opneembaarheid. In deze studie is de bruikbaarheid van intrinsiek fytase vanuit grondstoffen voor de afbraak van fytinezuur in grondstoffen onderzocht. De onderzochte grondstoffen waren voor een belangrijk deel biologisch geteelde grondstoffen voor toepassing in de biologische dierhouderij en bestonden uit DDGS, erwten, gerst, mais, maisglutenvoer, raapzaadschilfers, rogge, sojaschilfers, sojaschroot, tarwe, tarwegries, tarwezemelgrint en zonnebloemzaadschroot. Het gemiddelde percentage fosfor $(P)$ dat gebonden was in fytinezuur en anorganisch fosfaat bedroeg respectievelijk $73 \%$ en $14 \%$ voor de onderzochte grondstoffen, met uitzondering van rogge.

De enzymatische omzetbaarheid van fytinezuur naar oplosbaar anorganische fosfaat werd voor de genoemde grondstoffen in vitro bepaald door een incubatie gedurende 6 uur bij kamertemperatuur met en zonder toevoeging microbieel fytase. De gemiddelde enzymatische omzetbaarheid van fytinezuur-P zonder toevoeging van microbieel fytase bedroeg $30 \%$ en varieerde van $0 \%$ voor sojaschroot tot $85 \%$ voor tarwe. Toevoeging van microbieel fytase (500 FTU/kg) leidde tot een gemiddelde toename van de enzymatische omzetbaarheid van $17 \%$. De toename werd met name waargenomen bij grondstoffen met een lage intrinsieke fytase activiteit, zoals mais, erwten en sojaschroot, en werd met name veroorzaakt door een verhoogde afbraak van het oplosbare fytinezuur. Voor grondstoffen met een hoge intrinsieke fytase activiteit, zoals rogge en tarwe, was deze toename met name gekoppeld aan een toename van de oplosbaarheid van fytinezuur.

De hoogste fytase activiteit werd in de onderzochte grondstoffen aangetoond in rogge en tarwe. Op basis van deze activiteit en de hoge enzymatische omzetbaarheid van fytinezuur zijn beide producten als bron voor intrinsiek fytase verder onderzocht. Op basis van de gevonden effecten voor de toevoeging van microbieel fytase werden erwten, mais en sojaschilfers geselecteerd als fytinezuurbronnen voor verder onderzoek.

De aanwezigheid van intrinsiek fytase door toevoeging van rogge en tarwe leidde na incubatie van 6 uur bij kamertemperatuur tot een hogere P-beschikbaarheid (fractie oplosbaar anorganisch $\mathrm{P}$ ) van mais en sojaschilfers, terwijl voor erwten geen effect werd gevonden. Deze P-beschikbaarheid werd voor alle drie grondstoffen sterk verhoogd door een aanvullende incubatie gedurende 1 uur bij $37^{\circ} \mathrm{C}$. Een voor-incubatie met pepsine- $\mathrm{HCl}$ bij $\mathrm{pH} 2$ leidde tot een afname van de fytase activiteit die in het geval van sojaschilfers en erwten grotendeels kon worden gecompenseerd door het verlengen van de tijd bij de vervolg incubatie bij pH 5.5 van 2 naar 6 uur. In combinatie met mais kon de beschadiging van fytase door de lage $\mathrm{pH}$ niet worden gecompenseerd door een verlenging van de incubatie tijd. 


\section{$1 \quad$ Inleiding}

Het merendeel van fosfor $(P)$ in plantaardige grondstoffen is vastgelegd in fytinezuur dat bestaat uit een inositol ringstructuur waaraan zes fosfaatgroepen zijn gebonden (zie Figuur 1.1).

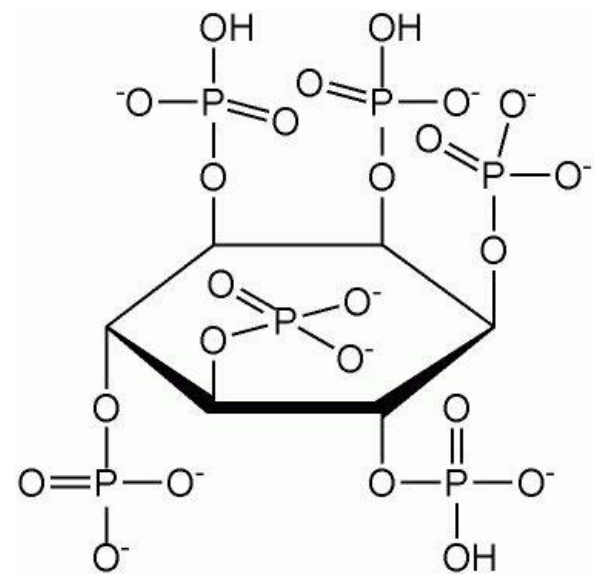

Figuur 1.1 Chemische structuur van fytinezuur.

Fytinezuur kan worden afgebroken met behulp van het enzym fytase maar dit is van nature slechts zeer beperkt aanwezig in het maagdarmkanaal van varkens en pluimvee waardoor het gebonden $\mathrm{P}$ voor de varkens en pluimvee nauwelijks beschikbaar is. Om aan de $\mathrm{P}$ behoefte te voldoen wordt anorganisch fosfaat, meestal in de vorm van mono- of dicalciumfosfaat (MCP of DCP), aan het voer toegevoegd. Deze aanpak heeft echter twee grote nadelen. Ten eerste zijn de beschikbare voorraden aan anorganisch P beperkt en deze zullen op den duur uitgeput zijn. Ten tweede leidt de aanwezigheid van onverteerd fytinezuur tot een hoog gehalte aan fosfor in de mest waardoor een groter areaal landbouwgrond nodig is om deze mest verantwoord af te zetten. Daarnaast is de lage verhouding stikstof $(\mathrm{N})$ : $\mathrm{P}$ ongunstig voor het gebruik als meststof omdat bij maximale toediening van $\mathrm{P}$ uit dierlijke mest de $\mathrm{N}$ voorziening nog onvoldoende is.

De potentiele oplossing voor beide problemen is het verbeteren van de verteerbaarheid van het organische fytinezuur door de toevoeging van het enzym fytase. Dit enzym splitst de fosfaat groepen van het inositol molecuul waardoor het slecht verteerbaar organisch $P$ wordt omgezet in goed opneembaar orthofosfaat. Sinds de jaren 90 wordt deze aanpak op grote schaal toegepast door standaard microbieel fytase (dosering veelal $\geq 500 \mathrm{FTU} / \mathrm{kg}$ ) aan voeders toe te voegen, waarmee in de praktijk de $\mathrm{P}$ verteerbaarheid van de grondstoffen aanzienlijk wordt verbeterd. De productie van microbieel fytase gebeurde aanvankelijk via gisten, echter de laatste jaren worden hiervoor steeds vaker genetische gemodificeerde bacteriën (GMO's) gebruikt.

Binnen de biologische landbouw is het gebruik van GMO's verboden, waardoor het gebruik van microbieel fytase voor het verbeteren van de $P$ verteerbaarheid niet mogelijk is. Een alternatief is het optimaal gebruik maken van intrinsiek fytase in grondstoffen, met name in granen door combinatie van dergelijke fytase-rijke grondstoffen met grondstoffen die rijk zijn aan fytine-P. De fytase activiteit in granen, vooral in rogge (en tarwe) is dusdanig hoog dat deze grondstoffen een aantrekkelijk alternatief zouden kunnen zijn voor microbieel fytase.

Het doel van dit onderzoek is om het gericht gebruik van intrinsiek fytase voor de afbraak van fytinezuur-P in biologische grondstoffen nader te onderzoeken. Deze afbraak kan zowel voor het verstrekken van het voer als tijdens het verteringsproces in het dier plaats vinden. Afbraak van fytinezuur-P voor het verstrekken van het voer heeft als voordeel dat de incubatie condities eenvoudiger zijn te optimaliseren en controle op de effectiviteit van de enzymatische omzetting mogelijk is. Om de praktische haalbaarheid van deze aanpak te bepalen, zijn de meeste incubaties bij kamertemperatuur uitgevoerd. Het onderzoek is opgebouwd uit vier fasen. 
De enzymatische omzetbaarheid van fytinezuur en de aanwezige fytase activiteit in diverse relevante grondstoffen zijn respectievelijk in de eerste en tweede fase onderzocht. Op basis van deze resultaten is een selectie van grondstoffen als bron van fytinezuur en fytase gemaakt die tijdens de derde en vierde fase verder zijn onderzocht. In de derde fase is de $P$ beschikbaarheid onder invloed van intrinsiek fytase voor deze combinaties onderzocht. In deze studie is $\mathrm{P}$ beschikbaarheid gedefinieerd als de fractie totaal opgelost anorganisch $\mathrm{P}$ ten opzichte van de totale hoeveelheid $\mathrm{P}$ in een monsters. Deze fractie bevat zowel het enzymatisch omzetbaar fytinezuur-P als het oorspronkelijk aanwezige anorganisch $\mathrm{P}$ in een monster. In fase vier is het effect van een voor-incubatie onder maagcondities $(\mathrm{pH} 2)$ op de $\mathrm{P}$ beschikbaarheid voor deze combinaties onderzocht om na te gaan of intrinsiek fytase bestand is tegen de condities in de maag en of deze condities de effectiviteit beïnvloeden.

Dit onderzoek is uitgevoerd in kader van het PPS-project Vermindering fosforexcretie door biologisch gehouden varkens en pluimvee, werkplan 2015 AF 15105) en de gebruikte protocollen en de keuze van de grondstoffen is in overleg met de begeleidingsgroep gebeurd. 


\section{Materiaal en Methode}

\section{$2.1 \quad$ Materiaal}

De gebruikte grondstoffen werden gekozen op basis van hun beschikbaarheid en relevantie voor de biologische dierhouderij. De meeste grondstoffen waren afkomstig van Reudink BV, Lochem (onderdeel van ForFarmers) aangevuld met enkele grondstoffen afkomstig uit eerder uitgevoerd verteringsonderzoek. De monstervoorbereiding bestond uit malen over $1 \mathrm{~mm}$. Een overzicht van de gebruikte grondstoffen (inclusief in welke fase deze zijn gebruikt), staat vermeld in Tabel 2.1

Tabel 2.1 Grondstoffen en de fase warin ze gebruikt zijn.

\begin{tabular}{ll} 
Grondstof & Fase \\
DDGS & 1 \\
\hline Erwten & $1+2+3+4$ \\
\hline Gerst & $1+2$ \\
\hline Mais & $1+2+3+4$ \\
\hline Maisglutenvoer & 1 \\
\hline Raapzaadschilfers & 1 \\
\hline Rogge & $1+2+3+4$ \\
\hline Sojaschilfers & $3+4$ \\
\hline Sojaschroot & 1 \\
\hline Tarwe & $1+2+3+4$ \\
\hline Tarwegries & $1+2$ \\
\hline Tarwezemelgrint & $1+2$ \\
\hline Zonnebloemzaadschroot & 1 \\
\hline
\end{tabular}

\section{$2.2 \quad$ Methode}

\subsubsection{Karakterisering grondstoffen}

De grondstoffen werden chemisch onderzocht op totaal- $P$, fytinezuur-P en anorganisch-P (is orthofosfaat-P). De gehalten aan totaal- $P$ in de diverse grondstoffen waren afkomst van eerder uitgevoerde analyses. Het gehalte aan anorganisch-P en fytinezuur-P werd enzymatisch bepaald met behulp van een commerciële testkit (Megazyme K-PHYT 08/14, Ierland), zoals beschreven door McKie en McCleary (2016). Deze methode was gebaseerd op een extractie van fytinezuur onder zure condities. Hiermee wordt beoogd alle fytinezuur beschikbaar te maken voor afbraak door fytase. Het extract werd met en zonder toevoeging van microbieel fytase en alkalische fosfatase geïncubeerd waarna in beide oplossingen het gehalte aan anorganisch-P spectrometrisch werd bepaald. Het gehalte gevonden in de oplossing zonder toevoeging van beide enzymen werd gebruikt voor de berekening van het gehalte aan anorganisch $\mathrm{P}$. Het verschil in gehalten aan anorganisch-P tussen de oplossing met en zonder toevoeging van beide enzymen werd gebruikt voor de berekening van het gehalte aan fytinezuur-P. Door afbraak onder invloed van intrinsiek fytase kan het gehalte aan fytinezuur-P onderschat worden, omdat het fytinezuur dat door intrinsiek fytase wordt afgebroken in de testkit niet meer als fytinezuur wordt gemeten.

\subsubsection{Enzymatisch omzetbaarheid fytinezuur}

De enzymatische omzetbaarheid van fytinezuur is de relatieve hoeveelheid fytinezuur die met of zonder toevoeging van microbieel fytase, bij $\mathrm{pH} 5.5$ in anorganisch fosfaat wordt omgezet. In tegenstelling tot de fytinezuur-P bepaling (2.2.1) bevatte deze bepaling geen extractie onder zure condities. De enzymatische omzetting geschiedt aan de hand van twee processen (zie figuur 3.1):

1. Oplossen van het aanwezige fytinezuur (proces 1)

2. Afbraak van het opgeloste fytinezuur (proces 2 ). 
De enzymatische omzetbaarheid werd gemeten via een incubatie van 2.5 gram grondstof in $50 \mathrm{ml}$ acetaatbuffer pH 5.5 met of zonder toevoeging van microbieel fytase bij kamertemperatuur. Het gehalte aan anorganisch $P$ in de oplossing werd naast de eerder genoemde processen ook beïnvloed door het oplossen van het in de grondstof aanwezige anorganisch P (proces 3 ) en het neerslaan van het vanuit de afbraak van fytinezuur gevormde anorganisch $P$ (proces 4 ). De berekening van de afbreekbaarheid van fytinezuur bevat een correctie voor beide processen.

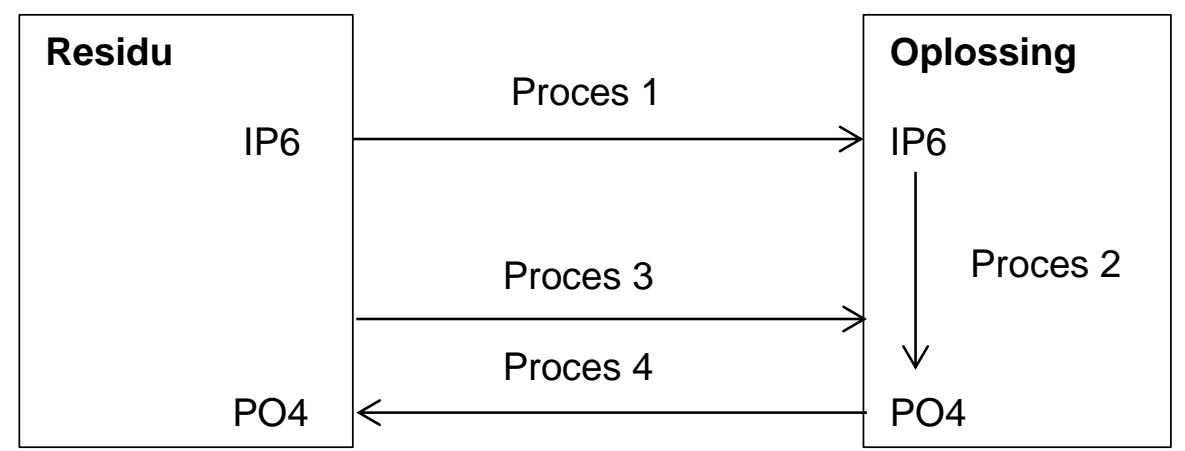

Figuur 3.1 Processen tijdens de incubatie ter bepaling van de afbreekbaarheid.

De incubatie werd na 6 uur gestopt waarna het residu en de vloeistof door middel van centrifugeren werden gescheiden. De hoeveelheid anorganisch $\mathrm{P}\left(\mathrm{PO}_{4}-\mathrm{P}\right)$ werd in de oplossing bepaald. De hoeveelheid aan fytinezuur-P (IP-P) en anorganisch $P$ werd in het residu via de eerder beschreven methode (zie 2.2.1) bepaald. Het volledige protocol staat vermeld in Bijlage 1. De oplosbaarheid van fytinezuur-P werd berekend als:

Oplosbaarheid IP-P (proces 1) $=100 \%-\left(I P-P_{\text {residu }}(\mathrm{mg}) * 100 \% /\right.$ IP- $\left.P_{\text {inweeg }}(\mathrm{mg})\right)$

De afbraak van oplosbaar fytinezuur werd berekend als:

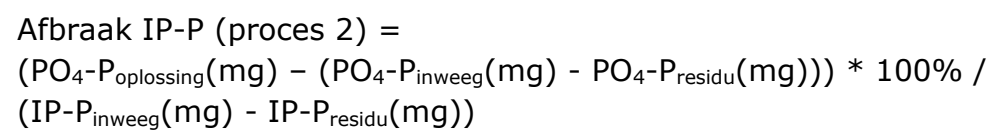

De enzymatische omzetbaarheid van fytinezuur-P werd berekend als:

Enzymatische omzetbaarheid IP-P = oplosbaarheid $*$ afbraak

\subsubsection{Activiteit fytase in grondstoffen}

De activiteit van intrinsiek fytase werd in een beperkt aantal grondstoffen bepaald. Deze selectie was gebaseerd op gegevens in de literatuur over de aanwezigheid van fytase in de betreffende grondstof. De activiteit werd bepaald op basis van het vrijkomen van oplosbaar anorganisch-P tussen 1 en 4 uur incubatie bij kamertemperatuur. Deze incubatie werd uitgevoerd met en zonder de toevoeging van een aanvullend substraat (opgelost natrium-fytaat) en met of zonder additioneel microbieel fytase (dosering: 500 en $5000 \mathrm{FTU} / \mathrm{kg}$ ). Het uitgebreide protocol staat in Bijlage 2 vermeld.

\subsubsection{Effectiviteit intrinsiek fytase}

Negen combinaties van 3 fytinezuur-P bevattende grondstoffen (erwten, mais en sojaschilfers) en 3 fytasebronnen (rogge, tarwe en microbieel fytase) werden gedurende 2 uur geïncubeerd waarna het beschikbare $P$ (opgelost fosfaat-P) vanuit de betreffende grondstoffen werd gemeten. Deze resultaten werden gecorrigeerd voor de bijdrage van beschikbaar $P$ vanuit de fytasebronnen (rogge en tarwe). Het protocol en de berekening staan in bijlage 3 vermeld. 


\subsubsection{Pepsine- $\mathrm{HCl}$ bestendigheid van intrinsiek fytase}

Het effect van een voor-incubatie met pepsine- $\mathrm{HCl}$ (maag simulatie) op de $\mathrm{P}$ beschikbaarheid werd voor 6 combinaties van 3 fytinezuur-P grondstoffen (erwten, mais en sojaschilfers) en 2 fytasebronnen (rogge en tarwe) onderzocht. Na de voor-incubatie werd de $\mathrm{P}$ beschikbaarheid bepaald door een incubatie bij pH 5.5 na 2 en 6 uur. Als referentie werd een voor-incubatie met water in plaats van pepsine- $\mathrm{HCl}$ gebruikt. Het protocol en de berekening staan in Bijlage 4 vermeld. 


\section{Resultaten}

\subsection{Karakterisering grondstoffen}

Het gehalte aan totaal-P in de grondstoffen varieerde van $2.8 \mathrm{~g} / \mathrm{kg}$ in mais tot $12.6 \mathrm{~g} / \mathrm{kg}$ in tarwezemelgrint (Tabel 3.1).

Het gemiddelde percentage fytinezuur-P (IP-P) ten opzichte van totaal-P was $70 \%$ en varieerde van $40 \%$ in rogge tot $85 \%$ in zonnebloemschilfers. Het lager percentage in DDGS was een gevolg van het productieproces waarbij de fytase in de toegevoegde gisten reeds voor een enzymatische omzetting van het aanwezige fytinezuur-P zorgde. Het afwijkende percentage in rogge ten opzichte van de andere granen werd zeer waarschijnlijk veroorzaakt door de hoge intrinsieke fytase activiteit in deze grondstof waardoor het gehalte aan fytinezuur-P met de gebruikte enzymatische methode werd onderschat. Het gemiddelde percentage fytinezuur-P ten opzichte van totaal-P zonder rogge was $73 \%$ en varieerde van $45 \%$ in DDGS tot $85 \%$ in zonnebloemschilfers.

Het gemiddelde percentage anorganisch $\mathrm{P}$ ten opzichte van totaal-P was $16 \%$ en varieerde van $3 \%$ in tarwe tot $49 \%$ in rogge. Het hoge percentage in DDGS was een gevolg van de enzymatische omzetting tijdens het productie proces. Het afwijkende percentage in rogge ten opzichte van de andere granen werd ook bij deze bepaling waarschijnlijk veroorzaakt door de hoge intrinsieke fytase activiteit in deze grondstof waardoor het gehalte aan anorganisch $\mathrm{P}$ met de gebruikte enzymatische methode werd overschat. Het gemiddelde percentage anorganisch $\mathrm{P}$ gebonden ten opzichte van totaal-P zonder rogge was $14 \%$ en varieerde van $3 \%$ in tarwe tot $40 \%$ in DDGS.

Het gemiddelde percentage rest-P ten opzichte van totaal-P was $14 \%$ en varieerde van niet aanwezig in zonnebloemschroot tot $21 \%$ in erwten en tarwe. Deze rest fractie bestond uit mogelijk aanwezig overige organische P-verbindingen, zoals fosforlipiden, slecht oplosbare P-bevattende zouten en onvolledige enzymatisch omgezette fytine-P.

Tabel $3.1 \quad$ Total gehalte aan $P$ en de percentages $I P-P ; P O_{4}-P$ en rest- $P$ ten opzichte van totaal$P$ in de onderzochte grondstoffen.

\begin{tabular}{lcccc} 
& & \multicolumn{2}{c}{ Percentage $(\%)$ t. O.v. total-P } \\
Grondstof & Gehalte P $(\mathrm{g} / \mathrm{kg})$ & IP-P & PO $_{4}-\mathrm{P}$ & \multicolumn{1}{c}{ Rest-P } \\
\hline DDGS & 8.3 & 45 & 40 & 16 \\
\hline Erwten & 3.9 & 70 & 9 & 21 \\
\hline Gerst & 3.4 & 74 & 11 & 15 \\
\hline Mais & 2.8 & 76 & 9 & 15 \\
\hline Maisglutenvoer & 9.1 & 72 & 25 & 4 \\
\hline Raapzaadschilfers & 9.0 & 81 & 7 & 12 \\
\hline Rogge & 3.4 & 40 & 49 & 12 \\
\hline Sojaschroot & 6.1 & 71 & 10 & 18 \\
\hline Tarwe & 3.2 & 76 & 3 & 21 \\
\hline Tarwegries & 9.4 & 81 & 7 & 12 \\
\hline Tarwezemelgrint & 12.6 & 73 & 12 & 15 \\
\hline Zonnebloemzaadschroot & 10.0 & 85 & 16 & -1
\end{tabular}

\subsection{Enzymatische omzetbaarheid fytinezuur}

De gemiddelde relatieve oplosbaarheid van fytinezuur-P (zonder toevoeging van fytase) was $78 \%$ en varieerde van $62 \%$ voor raapzaadschilfers tot $96 \%$ voor gerst (Tabel 3.2 ). De oplosbaarheid was voor schilfers en schroten duidelijk lager dan voor de granen. Incubatie met microbieel fytase verhoogde de gemiddelde relatieve oplosbaarheid van fytinezuur-P tot $91 \%$. De relatieve fytinezuur-P oplosbaarheid van de individuele grondstoffen na toevoeging van microbieel fytase varieerde van $77 \%$ voor sojaschroot en $98 \%$ voor tarwe. Toevoeging van microbieel fytase had het grootste additionele effect bij grondstoffen met een relatieve lage fytinezuur oplosbaarheid waardoor de verschillen in fytinezuur oplosbaarheid tussen de onderzochte grondstoffen afnam. 
Tabel 3.2 Relatieve oplosbaarheid ${ }^{1}$ van fytinezuur-P (in \%) per grondstof met en zonder toevoeging van microbieel fytase (500 FTU/g) na een incubatie gedurende 6 uur bij kamertemperatuur, en het verschil tussen beide (in \%).

\begin{tabular}{lccc} 
& \multicolumn{2}{c}{ Toevoeging fytase } & \\
Grondstof & Zonder & Met & Verschil \\
\hline DDGS & 74 & 80 & 6 \\
\hline Erwten & 75 & 93 & 18 \\
\hline Gerst & 96 & 97 & 1 \\
\hline Mais & 93 & 97 & 4 \\
\hline Maisglutenvoer & 86 & 94 & 8 \\
\hline Raapzaadschilfers & 62 & 88 & 26 \\
\hline Rogge & 77 & 97 & 20 \\
\hline Sojaschroot & 63 & 77 & 14 \\
\hline Tarwe & 85 & 98 & 13 \\
\hline Tarwegries & 81 & 97 & 16 \\
\hline Tarwezemelgrint & 83 & 96 & 13 \\
\hline Zonnebloemzaadschroot & 67 & 78 & 11 \\
\hline 1 & Bepaald als het verschil tussen fytinezuur-P in uitgangsmateriaal op t=0 en fytinezuur-P in
\end{tabular}

De gemiddelde relatieve afbraak van opgelost fytinezuur-P zonder toevoeging van microbieel fytase bedroeg $37 \%$ en varieerde van $0 \%$ bij sojaschroot tot $100 \%$ bij rogge en tarwe (zie Tabel 3.3). Deze extreme verschillen werden veroorzaakt door de variatie in intrinsieke fytase activiteit tussen de onderzochte grondstoffen. Deze activiteit was met name hoog in rogge, tarwe en tarwebijproducten en laag in de schroten/schilfers, mais en maisproducten. Opvallend was de relatief hoge afbraak in DDGS gezien de waarschijnlijk lage intrinsieke fytase activiteit in dit product. De gemiddelde relatieve enzymatische omzetting van opgelost fytinezuur-P met toevoeging van microbieel fytase bedroeg $51 \%$ en varieerde van $13 \%$ bij maisglutenvoer tot $100 \%$ bij rogge. Het grootste effect van microbieel fytase werd gevonden bij de grondstoffen DDGS, erwten, mais en sojaschroot. Ondanks dit effect bleef de relatieve enzymatische omzetting van opgelost fytinezuur-P voor het merendeel van de onderzochte grondstoffen ondanks de aanwezigheid van microbieel fytase kleiner dan $50 \%$.

Tabel 3.3 Relatieve afbraak van opgelost fytinezuur-P (in \%) met en zonder toevoeging van microbieel fytase (500 FTU/g) na een incubatie gedurende 6 uur bij kamertemperatuur, en het verschil tussen beide (in \%).

\begin{tabular}{|c|c|c|c|}
\hline & \multicolumn{2}{|c|}{ Toevoeging fytase } & \multirow[b]{2}{*}{ Verschil } \\
\hline Grondstof & Zonder & Met & \\
\hline DDGS & 53 & 83 & 30 \\
\hline Erwten & 14 & 43 & 29 \\
\hline Gerst & 53 & 66 & 13 \\
\hline Mais & 8 & 53 & 45 \\
\hline Maisglutenvoer & 5 & 13 & 8 \\
\hline Raapzaadschilfers & 11 & 21 & 10 \\
\hline Rogge & $>100$ & $>100$ & 0 \\
\hline Sojaschroot & 0 & 23 & 23 \\
\hline Tarwe & $>100$ & 98 & 0 \\
\hline Tarwegries & 55 & 45 & -10 \\
\hline Tarwezemelgrint & 29 & 34 & 13 \\
\hline Zonnebloemzaadschroot & 7 & 18 & 11 \\
\hline
\end{tabular}

De gemiddelde enzymatische omzetbaarheid van fytinezuur-P zonder toevoeging van microbieel fytase bedroeg $30 \%$ en varieerde van $0 \%$ voor sojaschroot tot $85 \%$ voor tarwe (tabel 3.4 ). Het gemiddelde effect van de toevoeging van microbieel fytase op de enzymatische omzetting van fytinezuur-P naar anorganisch fosfaat bedroeg $17 \%$ en varieerde van $0 \%$ bij tarwegries tot $44 \%$ bij mais. Voor grondstoffen met een lage intrinsieke fytase activiteit, zoals mais, erwten en sojaschroot, werd deze toename voornamelijk veroorzaakt door een verhoogde afbraak van het oplosbare fytinezuur. Voor grondstoffen met een hoge intrinsieke fytase activiteit, zoals rogge en tarwe, werd deze toename met name veroorzaakt door een toename van de oplosbaarheid van fytinezuur. 

microbieel fytase (500 FTU/g) na een incubatie gedurende 6 uur bij kamertemperatuur, en het verschil tussen beide (in \%).

\begin{tabular}{lccc} 
& Toevoeging fytase & Met & Verschil \\
Grondstof & Zonder & 66 & 27 \\
\hline DDGS & 39 & 40 & 29 \\
\hline Erwten & 11 & 64 & 13 \\
\hline Gerst & 51 & 52 & 44 \\
\hline Mais & 8 & 13 & 8 \\
\hline Maisglutenvoer & 5 & 19 & 12 \\
\hline Raapzaadschilfers & 7 & 97 & 20 \\
\hline Rogge & 77 & 23 & 23 \\
\hline Sojaschroot & 0 & 96 & 11 \\
\hline Tarwe & 85 & 45 & 0 \\
\hline Tarwegries & 45 & 34 & 5 \\
\hline Tarwezemelgrint & 29 & 18 & 11 \\
\hline Zonnebloemzaadschroot & 7 & &
\end{tabular}

Berekend als oplosbaarheid * afbraak

\subsection{Fytase activiteit in grondstoffen}

De fytase activiteit is in een beperkt aantal grondstoffen met en zonder toegevoegd substraat en microbieel fytase bepaald (Tabel 3.5). Door de afwijkende meetcondities, met name de incubatie periode en temperatuur ten opzichte van de standaard methode zijn de resultaten niet te vergelijken met de fytase activiteiten zoals beschreven in de literatuur.

Toevoeging van een fytinezuur-P bron als substraat leidde tot een sterke toename van de gemiddelde gemeten activiteit van 50 naar 276 FTU/kg, waaruit bleek dat de beschikbare hoeveelheid fytinezuur-P in deze grondstoffen limiterend was voor de enzymatische omzetting door het aanwezige fytase. Deze zeer beperkte beschikbaarheid werd met name waargenomen bij de onderzochte tarwebijproducten (tarwegries en tarwezemelgrint) en bij rogge.

Opvallend was het relatief geringe effect van de toegevoegde hoeveelheid microbieel fytase. De gemiddelde gemeten activiteit nam toe van 276 FTU/kg zonder toevoeging naar 289 en 345 FTU/kg bij een toevoeging van respectievelijk $500 \mathrm{FTU} / \mathrm{kg}$ en $5000 \mathrm{FTU} / \mathrm{kg}$. Dit geringe effect kan mogelijk worden veroorzaakt door de gebruikte methode voor het meten van de activiteit, namelijk de toename in de hoeveelheid oplosbaar anorganisch fosfaat tussen 1 en 4 uur. Het positieve effect van de toevoeging van microbieel fytase was wel zichtbaar in de snelheid waarmee fytaat werd afgebroken. Het vrijgemaakte P-fosfaat was gemiddelde 5.7 en $26.9 \mu \mathrm{mol}$ hoger bij toevoeging van respectievelijk 500 en $5000 \mathrm{FTU} / \mathrm{kg}$ microbieel fytase dan zonder toevoeging na een incubatie van 1 uur.

Tabel 3.5 Fytase activiteit ${ }^{1}(F T U / k g)$ in grondstoffen met en zonder toevoeging van fytinezuur-P (als substraat) en zonder (+ $0 \mathrm{FTU} / \mathrm{kg}$ ) en met $(+500 \mathrm{FTU} / \mathrm{kg}$ en $+5000 \mathrm{FTU} / \mathrm{kg}$ ) toegevoegd microbieel fytase.

\begin{tabular}{lcccc} 
& Geen toevoeging & & Toevoeging fytinezuur-P \\
Grondstoffen & +0 FTU & +0 FTU & +500 FTU $/ \mathrm{kg}$ & $+5000 \mathrm{FTU} / \mathrm{kg}$ \\
\hline Gerst & 49.6 & 80.0 & 123 & 233 \\
\hline Tarwe & 79.7 & 204 & 239 & 298 \\
\hline Tarwegries & 12.6 & 374 & 366 & 405 \\
\hline Rogge & 109 & 401 & 362 & 405 \\
\hline Tarwezemelgrint & $<0$ & 321 & 347 & 387
\end{tabular}

$1 \quad$ Gemeten als de toename in oplosbaar anorganisch fosfaat gedurende 1 en 4 uur incubatie bij kamertemperatuur.

Op basis van de gemeten fytaseactiviteiten en de hoge mate van afbreekbaarheid van het fytinezuur-P (tabel 3.4) zijn rogge en tarwe als fytase-bronnen geselecteerd. 


\subsection{Effectiviteit intrinsiek fytase}

Het effect van intrinsiek fytase vanuit rogge en tarwe op de P-beschikbaarheid (is de totale hoeveelheid oplosbaar anorganisch-P) van erwten, mais en sojaschilfers varieerde sterk tussen de grondstoffen (zie Tabel 3.6). De P-beschikbaarheid van erwten was laag en werd niet verhoogd door de aanwezigheid van het intrinsiek fytase vanuit rogge en tarwe in tegenstelling tot de toevoeging van microbieel fytase. De P-beschikbaarheid van mais was ook laag maar werd wel verhoogd door de aanwezigheid van het intrinsiek fytase vanuit rogge en tarwe. De P-beschikbaarheid na toevoeging van rogge was vergelijkbaar met de waarde gevonden na toevoeging van microbieel fytase. Het grootste effect van toevoeging van intrinsiek fytase op de P-beschikbaarheid werd voor sojaschilfers gevonden. Toevoeging van rogge leidde voor deze grondstof tot een hogere $\mathrm{P}$ beschikbaarheid dan additie van microbieel fytase. Het grotere toevoegingseffect van rogge op de P-beschikbaarheid van mais en sojaschilfers was gerelateerd aan de hoge intrinsieke fytase activiteit in dit product. Opvallend was dat het toevoegingseffect voor beide grondstoffen numeriek gelijk was. Door toevoeging van rogge en tarwe nam voor beide grondstoffen de P-beschikbaarheid met respectievelijk 18 en $8 \%$ toe. De maximale P-beschikbaarheid bedroeg slechts $41 \%$ en werd gevonden voor de combinatie sojaschilfers en rogge. De verschillen tussen de grondstoffen bleven ook na deze toevoeging aanwezig hetgeen in tegenstelling was tot de effecten gevonden na toevoeging van commercieel microbieel fytase.

Tabel $3.6 \quad P$ beschikbaarheid ${ }^{1}(\%)$ vanuit de grondstoffen erwten, mais en sojaschilfers zonder toevoeging van fytasebronnen, of met toevoeging van ofwel intrinsiek fytase vanuit rogge en tarwe of microbieel fytase na 2 uur incubatie bij kamertemperatuur.

\begin{tabular}{lcccc} 
& & \multicolumn{3}{c}{ Fytase bron } \\
Grondstoffen & Geen fytase bron & Rogge & Tarwe & +500 FTU $/ \mathrm{kg}$ \\
\hline Erwten & 14 & 9 & 14 & 27 \\
\hline Mais & 15 & 33 & 23 & 33 \\
\hline Sojaschilfers & 23 & 41 & 31 & 33
\end{tabular}

$1 \quad$ Berekend als totaal oplosbaar anorganisch $\mathrm{P} /$ totaal aanwezig $\mathrm{P} * 100$, waarbij gecorrigeerd is voor de P-beschikbaarheid vanuit rogge of tarwe.

\subsection{Pepsine- $\mathrm{HCl}$ bestendigheid intrinsiek fytase}

Het effect van een voor-incubatie met pepsine- $\mathrm{HCl}$ op de $\mathrm{P}$-beschikbaarheid was afhankelijk van de grondstoffen en de tijd van incubatie bij pH 5.5 (Tabel 3.7). De voor-incubatie leidde voor alle onderzochte combinaties tot een afname van de fytase activiteit zoals bleek uit de lagere Pbeschikbaarheid gemeten na een 2 uurs incubatie bij pH 5.5. De gemiddelde absolute afname van de $P$ beschikbaarheid voor de onderzochte grondstoffen varieerde van $13 \%$ voor sojaschilfers tot $72 \%$ voor mais. Voor sojaschilfers kon deze afname in $\mathrm{P}$ beschikbaarheid bijna volledig worden gecompenseerd door het gebruik van een langere incubatietijd bij $\mathrm{pH} 5.5$, zoals bleek uit de resultaten verkregen na 6 uurs incubatie. Voor erwten gold dit ook voor de incubatie met rogge. Echter bij gebruik van tarwe als fytasebron bleef de $P$ beschikbaarheid ook na 6 uurs incubatie duidelijk lager dan de resultaten zonder voor-incubatie. Het verlengen van de incubatietijd bij pH 5.5 leidde niet tot een toename van de $\mathrm{P}$ beschikbaarheid van mais. Blijkbaar leidde de voor-incubatie met pepsine- $\mathrm{HCl}$ in het geval van mais tot een volledige irreversibele beschadiging van het aanwezige intrinsieke fytase.

De $\mathrm{P}$ beschikbaarheden gevonden zonder voor-incubatie lagen duidelijk hoger dan de resultaten vanuit het vorige experiment (zie Tabel 3.6). Dit verschil werd waarschijnlijk veroorzaakt door de extra incubatiestap van 1 uur bij $37^{\circ} \mathrm{C}$ die een positief effect op de efficiëntie van de enzymatische reactie had. 
Tabel 3.7 P beschikbaarheid ${ }^{1}(\%)$ vanuit beide grondstoffen na eerst een voor-incubatie zonder en met pepsine- $\mathrm{HCl}$ gedurende 1 uur bij $37^{\circ} \mathrm{C}$, gevolgd door een na-incubatie gedurende 2 en 6 uurs bij pH 5.5 bij kamertemperatuur.

\begin{tabular}{lcccc} 
& \multicolumn{3}{c}{ Voor-incubatie bij $37^{\circ} \mathrm{C}$} \\
& Zonder pepsine & $-\mathrm{HCl}$ & \multicolumn{2}{c}{ Met pepsine $-\mathrm{HCl}$} \\
\hline Grondstof combinatie & 2 uur & 6 uur & 2 uur & 6 uur \\
\hline Sojaschilfers + rogge & 94 & 94 & 84 & 91 \\
\hline Erwten + rogge & 85 & 81 & 34 & 83 \\
\hline Mais + rogge & 100 & 100 & 26 & 25 \\
\hline Sojaschilfers + tarwe & 74 & 80 & 59 & 83 \\
\hline Erwten + tarwe & 74 & 74 & 13 & 46 \\
\hline Mais + tarwe & 79 & 79 & 10 & 12 \\
\hline 1
\end{tabular}

1 berekend als totaal oplosbaar anorganisch P / totaal aanwezig P * 100 


\section{Discussie}

Het doel van dit onderzoek was om de mogelijkheid van het gebruik van intrinsiek fytase vanuit grondstoffen als alternatief voor microbieel fytase te onderzoeken. De resultaten van dit onderzoek tonen aan dat dit mogelijk was maar dat de efficiëntie van deze aanpak sterk afhing van de gebruikte grondstoffen en condities waaronder de incubaties plaatsvonden.

De onderzochte grondstoffen varieerden sterk wat betreft de enzymatische omzetting van fytinezuurP. Deze afbraak werd bepaald door twee processen: het oplossen van fytinezuur en de afbraak van opgelost fytinezuur. Voor de meeste onderzochte grondstoffen bleek dat de afbraak van fytinezuur-P met name door een lage afbraak van opgelost fytinezuur werd veroorzaakt. Voor erwten, mais en sojaschroot werd dit veroorzaakt door een lage intrinsieke fytase activiteit die door toevoeging van microbieel fytase kon worden gecompenseerd wat leidde tot een verhoogde afbraak van fytinezuur-P. Voor maisglutenvoer, raapzaadschilfers en zonnebloemzaadschroot bleef de afbraak van fytinezuur- $P$ ondanks de toevoeging van microbieel fytase erg laag $(<20 \%)$. In deze grondstoffen waren blijkbaar andere factoren, zoals toegankelijkheid en complexvorming van fytinezuur, verantwoordelijk voor de lage afbraak. De hoogste afbraak van fytinezuur-P werd aangetoond in onbehandelde grondstoffen met een hoge intrinsieke fytase activiteit, zoals rogge en tarwe. Deze grondstoffen zijn derhalve als potentiele alternatieven voor microbieel fytase binnen dit onderzoek nader onderzocht.

De effectiviteit van intrinsiek fytase vanuit rogge en tarwe was afhankelijk van de gebruikte grondstoffen en de gebruikte incubatie condities. Voor mais en sojaschilfers nam de P beschikbaarheid ten gevolge van de aanwezigheid van het intrinsiek fytase duidelijk toe terwijl voor erwten geen positief effect werd waargenomen bij kamertemperatuur. Deze effectiviteit verbeterde aanzienlijk indien een aanvullende incubatie gedurende één uur bij $37^{\circ} \mathrm{C}$ werd uitgevoerd. Een mogelijke reden voor dit effect is de betere ontsluiting van zowel de fytinezuur als het intrinsiek fytase en de hogere fytase activiteit bij deze hogere temperatuur. Voor-incubatie met pepsine-HCl leidde tot een afname van de intrinsieke fytase activiteit echter de mate van beschadiging was opvallend genoeg ook afhankelijk van de gebruikte fytinezuur grondstof. De sterkste beschadiging werd waargenomen bij het gebruik van mais, die niet kon worden gecompenseerd door een langere incubatie bij pH 5.5. De mate van beschadiging van het intrinsieke fytase door de pepsine-HCl voor-incubatie was mogelijk negatief gerelateerd aan het gehalte aan eiwit in de aanwezige grondstoffen. Het hogere eiwit gehalte in sojaschilfers werkte mogelijk beschermd doordat het fytase eiwit daardoor minder bloot stond aan de proteolytische activiteit van het aanwezige pepsine.

De resultaten van deze studie tonen aan dat intrinsiek fytase vanuit de individuele grondstoffen kan bijdragen aan de afbraak van fytinezuur in het voer. De mate van afbraak is echter afhankelijk van de gebruikte grondstoffen, zowel voor de fytinezuur als de fytase bron(nen), en de incubatie condities, met name temperatuur en tijd. Bij het toepassen van deze aanpak in de praktijk moet met deze variatie rekening te worden gehouden. De resultaten tonen aan dat deze aanpak leidt tot een goede afbraak van fytinezuur-P bij $37^{\circ} \mathrm{C}$ en dat deze aanpak mogelijk tot een significante verbetering van de totale $P$ verteerbaarheid in voeders kan leidden. Uit de maag simulatie blijkt tevens de kans op irreversibele beschadiging van fytase na incubatie bij een lage $\mathrm{pH}$. Deze kans op beschadiging is naast de eerder genoemde voordelen, zoals controleerbaarheid van incubatie condities en effectiviteit, een extra argument om de praktische haalbaarheid van voor-incubatie van het voer of de individuele grondstoffen met fytase te onderzoeken. Deze praktische haalbaarheid dient verder uitgezocht te worden. 


\section{Conclusies}

De belangrijkste conclusies uit deze studie zijn als volgt:

- De gemiddelde enzymatische omzetbaarheid van fytinezuur-P zonder toevoeging van microbieel fytase bedroeg $30 \%$ en varieerde van $0 \%$ voor sojaschroot tot $85 \%$ voor tarwe.

- Toevoeging van microbieel fytase (500 FTU/kg) leidde tot een gemiddelde toename van de enzymatische omzetbaarheid van $17 \%$. De toename werd met name waargenomen bij grondstoffen met een lage intrinsieke fytase activiteit, zoals mais, erwten en sojaschroot, en werd met name veroorzaakt door een verhoogde afbraak van het oplosbare fytinezuur. Voor grondstoffen met een hoge intrinsieke fytase activiteit, zoals rogge en tarwe, was deze toename met name gekoppeld aan een toename van de oplosbaarheid van fytinezuur.

- De hoogste fytase activiteit werd in de onderzochte grondstoffen aangetoond in rogge en tarwe.

- De aanwezigheid van intrinsiek fytase door toevoeging van rogge en tarwe leidde tot een hogere Pbeschikbaarheid (fractie oplosbaar anorganisch $\mathrm{P}$ ) van mais en sojaschilfers, terwijl voor erwten geen effect werd gevonden. Deze P-beschikbaarheid werd voor alle drie grondstoffen sterk verhoogd door een aanvullende incubatie gedurende 1 uur bij $37^{\circ} \mathrm{C}$.

- Een voor-incubatie met pepsine-HCl bij pH 2 leidde tot een afname van de fytase activiteit die in het geval van sojaschilfers en erwten grotendeels kon worden gecompenseerd door de verlengen van de tijd bij de vervolg incubatie bij pH 5.5 van 2 naar 6 uur. In combinatie met mais kon de beschadiging van fytase door de lage $\mathrm{pH}$ niet worden gecompenseerd door een verlenging van de incubatie tijd.

Praktische aanbevelingen

Deze studie toont aan dat het mogelijk is om de P-beschikbaarheid van biologische grondstoffen, waarvan het fytaat goed oplosbaar is, in sterke mate te verhogen door deze te combineren met biologische grondstoffen met een hoog intrinsiek fytasegehalte. Voorwaarde is wel dat fytaat en fytase voldoende tijd krijgen om met elkaar te reageren. Er is behoefte aan dierexperimenten om de gevonden in vitro effecten onder in vivo condities te valideren. Tevens dient nagegaan te worden wat de effecten van de procescondities in een mengvoerfabriek zijn op de fytaseactiviteit van de biologische grondstoffen. 


\section{Referenties}

McKie, V. A., and B. V. McCleary. 2016. A novel and rapid colorimetric method for measuring total phosphorus and phytic acid in foods and animal feeds. J. AOAC Int. 99(3):738-743. 


\section{Bijlage 1 Protocol Enzymatische omzetbaarheid fytinezuur $P$}

\section{Protocol:}

Elke grondstof wordt met en zonder toegevoegde fytase in de zelfde serie geïncubeerd.

1. 2.5 gram van de te onderzoeken grondstof wordt gesuspendeerd in $50 \mathrm{ml} 0.25 \mathrm{M}$ Acetaat buffer $\mathrm{pH}$ 5.5

Bereiding buffer: Los $1,82 \mathrm{~g}$ azijnzuur, 30,02 g natrium acetate, 0,147 g calcium chloride en $1 \mathrm{ml}$ Brij 35 oplossing $(100 \mathrm{~g} / \mathrm{l})$ op in $900 \mathrm{ml}$ water en vul aan tot $1000 \mathrm{ml}$ ). Controleer of de $\mathrm{pH}$ van de oplossing tussen 5.45 en 5.55 ligt.

2. Voeg per grondstof aan één van de oplossingen 1.25 FTU fytase toe.

Bereiding: Uitgangsmateriaal Phyzyme (5000 FTU/m/). Verdun deze oplossing 1000 x met water (oplossing: $5 \mathrm{FTU} / \mathrm{ml}$ ). Voeg hiervan $0.25 \mathrm{ml}$ aan het mengsel toe.

3. Incubeer de mengsels gedurende 6 uur onder constant roeren bij kamertemperatuur

4. Neem na 6 uur twee monsters van $1 \mathrm{ml}$ vanuit het vloeistof (laat deze even bezinken) en voeg 1 $\mathrm{ml}$ TCA (40\%). Vortex kracht en centrifugeer de vloeistof gedurende 15 minuten bij $20000 \mathrm{~g}$.

5. Breng het supernatant verkregen in stap 4 over in een eppendorf cupje. Bewaar deze oplossing onder gekoelde conditie.

6. Bepaal het gehalte aan $P$ in het supernatant.

7. Centrifugeer het resterende mengel na afloop van de incubatie bij $20000 \mathrm{~g}$ en verwijder het supernatant.

8. Breng het residu kwantitatief over in een gewogen schaaltje en droog het overnacht bij $70 \circ \mathrm{C}$.

9. Weeg het schaaltje inclusie residu en bepaal in het residu het gehalte aan fytinezuur-P en anorganische $\mathrm{P}$ via de Megazyme methode. 


\section{Bijlage 2 Protocol: Bepaling van de fytase activiteit}

\section{Protocol:}

Een geselecteerde groep grondstoffen worden met het onderstaande protocol geanalyseerd.

1. 1 gram van de te onderzoeken grondstof wordt gesuspendeerd in $50 \mathrm{ml} 0.25 \mathrm{M}$ Acetaat buffer $\mathrm{pH}$ 5.5 waarin natrium fytaat is opgelost $(9.2 \mathrm{~g} / \mathrm{l})$.

2. Per serie wordt $0 ; 0.1$ en $1.0 \mathrm{ml}$ verdunde fytase oplossing aan $50 \mathrm{ml} 0.25 \mathrm{M}$ Acetaat buffer $\mathrm{pH} 5.5$ waarin natrium fytaat is opgelost $(9.2 \mathrm{~g} / \mathrm{l})$ toegevoegd. Deze oplossingen komen overeen met 0 , 0.5 en 5 FTU.

Uitgaande van 1 gram monster komen deze activiteiten overeen met 0; 500 FTU/kg en 5000 FTU/kg hetgeen de natuurlijke range in grondstoffen bestrijkt.

3. Incubeer de mengsels gedurende 4 uur onder constant roeren bij kamertemperatuur

4. Neem na 1 en 4 uur, twee monsters van $1 \mathrm{ml}$ vanuit het vloeistof en voeg $1 \mathrm{ml}$ TCA (40\%). Vortex kracht en centrifugeer de vloeistof gedurende 15 minuten bij $20000 \mathrm{~g}$.

5. Breng het supernatant verkregen na stap 4 over in een eppendorf cupje. Bewaar deze oplossing onder gekoelde conditie.

6. Bepaal het gehalte aan $\mathrm{P}$ in het supernatant. 


\section{Bijlage 3 Protocol: Bepaling van de effectiviteit van intrinsiek fytase}

\section{Protocol:}

Een beperkte groep van combinaties van grondstoffen zijn met het onderstaande protocol geanalyseerd.

Protocol:

1. 0.5 gram van de te onderzoeken grondstof (fytinezuur bron) en 0.5 gram van een grondstof (fytase) en 0 en $0.1 \mathrm{ml}$ van de verdunde fytase oplossing wordt gesuspendeerd in $25 \mathrm{ml} 0.25 \mathrm{M}$ Acetaat buffer pH 5.5 .

2. 1.0 gram van de te onderzoeken grondstof (fytaat bron) en 0 en $0.1 \mathrm{ml}$ van de verdunde fytase oplossing wordt gesuspendeerd in $25 \mathrm{ml} 0.25 \mathrm{M}$ Acetaat buffer $\mathrm{pH} 5.5$.

3. $1.0 \mathrm{gram}$ van de te onderzoeken grondstof (fytase bron) en $0 \mathrm{ml}$ van de verdunde fytase oplossing wordt gesuspendeerd in $25 \mathrm{ml} 0.25 \mathrm{M}$ Acetaat buffer pH 5.5 .

3. Incubeer de mengsels gedurende 2 uur onder constant roeren bij kamertemperatuur (Hiermee worden de condities in de praktijk benaderd)

4. Neem na, 2 uur twee monsters van $1 \mathrm{ml}$ vanuit het vloeistof en voeg $1 \mathrm{ml}$ TCA (40\%). Vortex kracht en centrifugeer de vloeistof gedurende 15 minuten bij $20000 \mathrm{~g}$.

5. Breng het supernatant verkregen na stap 4 over in een eppendorf cupje. Bewaar deze oplossing onder gekoelde conditie.

6. Bepaal het gehalte aan $\mathrm{P}$ in het supernatant.

\section{Berekening:}

$P$ beschikbaarheid:

Fytinezuur bron: (gehalte $\mathrm{P}$ in supernatant $(\mathrm{mg} / \mathrm{l}) * 2 * 0.025) /($ inweeg $(\mathrm{g}) *$ gehalte $\mathrm{P}(\mathrm{g} / \mathrm{kg})$ ) * $100 \%$

Waarin 2 is verdunningsfactor en 0.025 is buffervolume in I.

Voor Sojaschilfers:

$P$ in supernatant : $28.9 \mathrm{mg} / \mathrm{l}$; inweeg : 1.0013 ; gehalte : $6.1 \mathrm{~g} / \mathrm{kg} \rightarrow$

Beschikbaarheid is $23.6 \%$

Fytase bron: (gehalte $\mathrm{P}$ in supernatant $(\mathrm{mg} / \mathrm{l}) * 2 * 0.025$ ) / (inweeg $(\mathrm{g}) *$ gehalte $\mathrm{P}(\mathrm{g} / \mathrm{kg})$ ) * $100 \%$ Waarin 2 is verdunningsfactor en 0.025 is buffervolume in $\mathrm{I}$.

Voor Rogge:

$\mathrm{P}$ in supernatant : $74.8 \mathrm{mg} / \mathrm{l}$; inweeg : 1.0041 ; gehalte : $3.8 \mathrm{~g} / \mathrm{kg} \rightarrow$

Beschikbaarheid is $98 \%$

Fytinezuur bron na toevoeging van fytase bron :

Fytinezuur bron: (gehalte $\mathrm{P}$ in supernatant $(\mathrm{mg} / \mathrm{l}) * 2 * 0.025)$ - (inweeg fytasebron $(\mathrm{g}) *$ gehalte $\mathrm{P}$ in fytasebron $(\mathrm{g} / \mathrm{kg}) *($ beschikbaarheid fytasebron $(\%) / 100)) * 100 /($ inweeg fytinezuur bron $(\mathrm{g}) *$ gehalte P fytinezuurbron $(\mathrm{g} / \mathrm{kg})) * 100 \%$

Voor sojaschilfers in combinatie met rogge:

$P$ in supernatant : 63.6 ;

Sojaschilfers: inweeg $=0.5001 \mathrm{~g}$ en gehalte $=6.1 \mathrm{~g} / \mathrm{kg}$

Rogge : inweeg $=0.5003 \mathrm{~g}$, gehalte $=3.8 \mathrm{~g} / \mathrm{kg}$ en beschikbaarheid $=98 \%$

$\mathrm{P}$ beschikbaarheid (sojaschilfers) is $43.6 \%$ 


\section{Bijlage 4 Protocol: Pepsine-HCl bestendigheid van intrinsiek fytase}

\section{Protocol:}

Een beperkte groep van combinaties van grondstoffen zijn met het onderstaande protocol geanalyseerd.

Protocol:

1. 0.5 gram van de te onderzoeken grondstof (fytaat bron) en 0.5 gram van een grondstof (fytase) wordt gesuspendeerd in $25 \mathrm{ml}$ zoutzuur oplossing $(\mathrm{pH} 2)$ en $0.5 \mathrm{ml}$ pepsine oplossing ( $1 \mathrm{~g}$ pepsin (2000FIP-U/g; Merck 7190) in $100 \mathrm{ml} 0.2 \mathrm{M} \mathrm{HCl}$ ) (met pepsine- $\mathrm{HCl}$ incubatie).

2. 0.5 gram van de te onderzoeken grondstof (fytaat bron) en 0.5 gram van een grondstof (fytase) wordt gesuspendeerd in $25 \mathrm{ml}$ water (zonder pepsine- $\mathrm{HCl}$ incubatie)

3. Het mengsel wordt gedurende 1 uur geïncubeerd bij $37 \circ \mathrm{C}$.

4. Neutraliseer de $\mathrm{pH}$-monsters met $0.25 \mathrm{ml} 1 \mathrm{M} \mathrm{NaOH}$.

5. Voeg $25 \mathrm{ml} 0.25 \mathrm{M}$ Acetaat buffer pH 5.5 toe en breng de pH tussen 5.45 en 5.55.

6. Incubeer de mengsels gedurende 2 en 6 uur onder constant roeren bij kamertemperatuur.

5. Neem na de incubatie van $1 \mathrm{ml}$ vanuit het vloeistof en voeg $1 \mathrm{ml} \mathrm{TCA}(40 \%)$. Vortex kracht en centrifugeer de vloeistof gedurende 15 minuten bij $20000 \mathrm{~g}$.

6. Breng het supernatant verkregen na stap 5 over in een eppendorf cupje. Bewaar deze oplossing onder gekoelde conditie.

7. Bepaal het gehalte aan $\mathrm{P}$ in het supernatant.

\section{Berekening}

P-beschikbaarheid (in \%) =

(gehalte $\mathrm{P}$ in supernatant $(\mathrm{mg} / \mathrm{l}) * 2 * 0.050) /$ (inweeg fytinezuur bron $(\mathrm{g}) *$ gehalte $\mathrm{P}$ fytinezuur bron $(\mathrm{g} / \mathrm{kg})+$ inweeg fytase bron $(\mathrm{g}) *$ gehalte P fytase bron $(\mathrm{g} / \mathrm{kg})) * 100 \%$ 

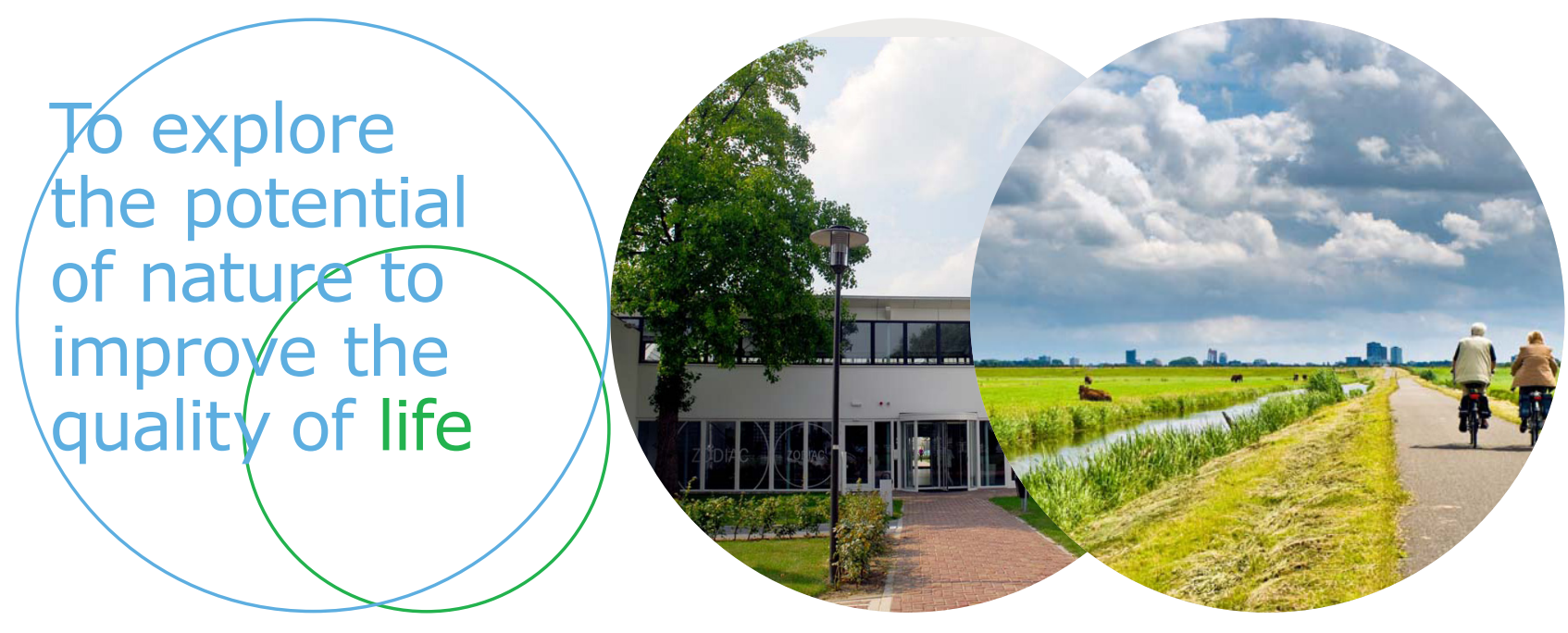

Wageningen Livestock Research Postbus 338

6700 AH Wageningen

T 0317483953

E info.livestockresearch@wur.nl www.wur.nl/livestock-research
Wageningen Livestock Research ontwikkelt kennis voor een zorgvuldige en renderende veehouderij, vertaalt deze naar praktijkgerichte oplossingen en innovaties, en zorgt voor doorstroming van deze kennis. Onze wetenschappelijke kennis op het gebied van veehouderijsystemen en van voeding, genetica, welzijn en milieu-impact van landbouwhuisdieren integreren we, samen met onze klanten, tot veehouderijconcepten voor de $21 \mathrm{e}$ eeuw.

De missie van Wageningen University \& Research is 'To explore the potential of nature to improve the quality of life'. Binnen Wageningen UR bundelen 9 gespecialiseerde onderzoeksinstituten van stichting DLO en Wageningen University hun krachten om bij te dragen aan de oplossing van belangrijke vragen in het domein van gezonde voeding en leefomgeving. Met ongeveer 30 vestigingen, 6.000 medewerkers en 10.000 studenten behoort Wageningen UR wereldwijd tot de aansprekende kennisinstellingen binnen haar domein. De integrale benadering van de vraagstukken en de samenwerking tussen verschillende disciplines vormen het hart van de unieke Wageningen aanpak. 